\title{
PENGEMBANGAN MODEL PEMBELAJARAN DALAM PELATIHAN BERBASIS LINGKUNGAN BAGI GURU MADRASAH ALIYAH PROGRAM ILMU PENGETAHUAN SOSIAL
}

\author{
Endang Sutisnowati ${ }^{1}$ \\ Badan Litbang dan Diklat Kementerian Agama \\ esutisnowati@gmail.com
}

https://doi.org/10.36052/andragogi.v9i1.229

Diterima: 23 Mei 2021 | Disetujui: 2 Juni 2021 | Dipublikasikan: 30 Juni 2021

\begin{abstract}
Abstrak
Penelitian ini bertujuan untuk mengembangkan model pembelajaran dalam pelatihan berbasis lingkungan bagi guru Madrasah Aliyah program Ilmu Pengetahuan Sosial Permasalahan mendasar dalam penelitian ini, adalah pembelajaran pada program Ilmu Pengetahuan Sosial Madrasah Aliyah yang dimulai dari perencanaan sampai dengan evaluasi belum berbasis lingkungan atau kontekstual, oleh karena itu penelitian ini menggunakan jenis penelitian pengembangan dengan metode pengembangan untuk menghasilkan produk tertentu dan menguji keefektifan produk yang dianalisis secara kuatitatif maupun deskriptif kualitatif. Kesimpulan hasil penelitian ini menghasilkan dua produk, yaitu pengembangan model pembelajaran pelatihan yang berupa desain program pembelajaran pelatihan berbasis lingkungan yang divalidasi oleh para ahli, memperoleh skor rata-rata $94 \%$ dan panduan pembelajaran berbasis lingkungan dengan pola blended learning, skor rata-rata 98\%. Kesimpulan hasil tahapan penelitian pengembangan model pembelajaran pelatihan berbasis lingkungan, diperoleh skor rata-rata $89,91 \%$ yang disertai produk panduan pembelajaran berbasis lingkungan memperoleh skor rata-rata $88,25 \%$, sedangkan kemampuan guru menyusun soal HOTS sebagai alat evaluasi dan merupakan satu kesatuan dalam pembelajaran berbasis lingkungan ini, skor rata-rata $89,53 \%$. Dengan demikian produk pengembangan model ini sangat layak untuk menjadi produk sistem di Pusdiklat Tenaga Teknis Pendidikan dan Keagamaan.
\end{abstract}

Kata Kunci: Pengembangan Model pembelajaran, Lingkungan, Program Ilmu Pengetahuan Sosial

\begin{abstract}
This study aims to develop a learning model in environmental-based training for teachers of Madrasah Aliyah Social Sciences program. The fundamental problem in this research, is that learning in the Madrasah Aliyah Social Science program which starts from planning to evaluation has not been based on the environment or contextual, therefore this research uses a type of development research with development methods to produce certain products and test the effectiveness of the products being analyzed. qualitatively and qualitatively descriptive. The conclusion of this study resulted in two products, namely the development of a training learning model in the form of an environment-based training learning program design which was validated by experts, obtaining an average score of $94 \%$ and an environment-based learning guide with a blended learning pattern, an average score of $98 \%$. The conclusion of the research stages of developing an environment-based training learning model, obtained an average score of $89.91 \%$ accompanied by environmental-based learning guide products obtained an average score of $88.25 \%$, while the teacher's ability to prepare HOTS questions as an evaluation tool and is an integral part in this environment-based learning, the average score is $89.53 \%$. Thus the product of this model development is very feasible to be a system product at the Education and Training Center for Technical Education and Religious Personnel.
\end{abstract}

Keywords: Learning Model Development, Environment, Social Science Program

This work is licensed under a Creative Commons Attribution-NonCommercial 4.0 International License 


\section{PENDAHULUAN}

P erkembangan ilmu dan teknologi pada era disrupsi dan 4.0 menuntut adanya transformasi pembelajaran, belajar lebih fleksibel dengan memanfaatkan ragam sumber belajar, interaksi dengan lingkungan, ruang kelas terbuka, dan belajar dapat terjadi di mana saja. Pengkondisian lingkungan sebagai sumber belajar dianalisis, dikembangkan, dan diintegrasikan ke dalam materi ajar yang memadukan antara konsep dan fakta, sehingga pembelajaran lebih bermakna (meaningfull learning), dan pencapaian kompetensi sikap, pengetahuan dan keterampilan menjadi komprehensif.

Berdasarkan hasil pra penelitian pada tanggal 14 dan 21 September 2019 September 2019 melalui angket dan wawancara secara langsung kepada guru Sosiologi Geografi, Ekonomi, dan Sejarah (program IPS) di MA Kota Bekasi tentang pemberdayaan lingkungan dan kegiatan pembelajaran yang mengaitkan antara konsep dan faktual, hasil rata-rata $47 \%$ dalam menyusun rencana pembelajaran belum mengembangakan materi yang kontekstual, masih download di internet, dan copy paste hasil kegiatan di MGMP. Hasil wawancara dengan guru-guru tersebut, menyatakan belum mengembangkan materi yang dikolaborasi dengan lingkungan, sehingga lingkungan belum menjadi sumber belajar, pembelajaran masih bersifat konseptual, konvensional dan selalu dilakukan di dalam ruang kelas. Berkaitan dengan menyusun soal berbasis HOTS sebagai alat evaluasi dalam pembelajaran diperoleh data $58 \%$ guru program IPS masih belum memahami tentang ciri maupun penyusunan soal HOTS.

Berdasarkan permasalahan tersebut, penekanannya pada permasalahan pembelajaran yang dilengkapi dengan soal HOTS sebagai alat evaluasi. Oleh karena itu fokus masalah dalam penelitian ini, adalah bagaimanakah cara mengembangkan model pembelajaran dalam pelatihan berbasis lingkungan yang dimulai dari perencanaan sampai evaluasi bagi guru madrasah aliyah pada program IPS ?

Untuk memecahkan permasalahan tersebut, maka tujuan penelitian pengembangan ini, adalah untuk mengembangkan model pembelajaran dalam pelatihan berbasis lingkungan bagi guru madrasah aliyah program IPS, yang menggunakan pola pembelajaran blended learning dengan outdoor learning pada kegiatan tatap muka, serta menyusun soal Higher Order Thinking Skill (HOTS) sebagai alat evaluasi dalam pembelajaran.

Pembelajaran pada program IPS di madrasah aliyah sarat dengan pembelajaran yang kontekstual atau pembelajaran yang mengkolaborasi materi secara konseptual dengan kontekstual. Sasaran dalam penelitian ini, adalah pembelajaran pada program IPS, yang meliputi mata pelajaran Geografi, Ekonomi, Sosiologi dan Sejarah. Pembelajaran program IPS syarat dengan fenomena sosial pada lingkungan, sebagai materi yang kontekstual, hal itu seiring dengan NCSS (2002) yang menegaskan program IPS sebagai ilmu secara mandiri atau terpadu untuk mempromosikan berbagai kompetensi kemanusiaan. Karakteristik program IPS digambarkan oleh NCSS sebagai pembelajaran yang powerful, ditandai dengan pengalaman belajar yang bermakna, terpadu, berbasis nilai, menantang, dan mengaktifkan.

Berkaitan dengan pengalaman belajar, sesuai dengan teori active learning dari L. Dee Fink (2013) yang menunjukkan bahwa semua aktivitas belajar melibatkan berbagai pengalaman atau dialog, yaitu dialog dengan diri sendiri dan dialog dengan orang lain, sedangkan dua jenis pengalaman adalah observasi (observing) dan melakukan (doing). Perkembangan konsep tersebut dikenal dengan pengalaman belajar. Hal itu senada dengan konsepnya Wyatt \& Looper (1999) yang dikenal dengan successful learning comes from doing atau kerucut pengalaman belajar, bahwa belajar akan diperoleh melalui keterlibatan dalam diskusi 50\% menyajikan/presentasi, 70\% dan bermain peran/simulasi/mengerjakan hal yang nyata $90 \%$, dengan tingkat keterlibatan yang dimulai dari verbal, visual, keaktifan dan melakukan.

Dasar teori pembelajaran berbasis lingkungan dengan pengkondisian lingkungan, adalah sesuai dengan teori belajar dari Skinner (1990), psikologi behavioristik, memandang bahwa pola-pola perilaku dapat dibentuk melalui proses pembiasaan, penguatan (reinforcement) dengan mengkondisikan stimulus (conditioning) 
dalam lingkungan (environment). Piaget (1988) dikenal dengan ahli psikologi kognitif (teori konstruktivisme) menyatakan bahwa individu membangun sendiri pengetahuannya dari pengalamannya sendiri dengan lingkungan. Teori behavioristik dan konstruktivisme didukung Vigotsky dalam Haryanto (2011), dikenal dengan teori sosio kultural, menekankan interaksi antara aspek "internal" dan "eksternal" dari pembelajaran, yaitu lingkungan sosial pembelajaran

Penelitian pengembangan ini menghasilkan dua produk, yaitu, pengembangan model pembelajaran dalam pelatihan yang berupa desain program pembelajaran pelatihan berbasis lingkungan, dan panduan pembelajaran berbasis lingkungan dengan pola blended learning yang divalidasi oleh para ahli dari perguruan tinggi, maupun praktisi pendidikan, yaitu ahli kurikulum, IPS, pembelajaran dan bahasa. Harapan dari hasil penelitian ini adalah, adanya transformasi pengembangan model pembelajaran pelatihan yang mengkolaborasi lingkungan sosial sebagai kelas terbuka, elaborasi pengembangan materi konsep dan faktual serta soal HOTS sebagai alat evaluasi pembelajaran berabsis lungkungan yang dikuasai guru madrasah aliyah pada program IPS. Hal tersebut sebagaimana tuntutan kompetensi pembelajaran abad 21 diantaranya mengakomodir, dan memberdayakan lingkungan sosial sebagai alat (tools) menuju perubahan maupun peningkatan kompetensi guru madarsah aliyah pada program IPS melalui pembelajaran berbasis lingkungan.

Dengan demikian penelitian ini membawa manfaat, yaitu: (a) bagi lembaga Pusdiklat Tenaga Teknis Pendidikan dan Keagamaan sebagai bahan pengembangan desain kurikulum dan perbaikan maupun perubahan pembelajaran pelatihan khususnya pada jenis pelatihan program IPS MA; (b) bagi Widyaiswara, sebagai tantangan dan peluang untuk meningkatkan mutu pembelajaran berbasis lingkungan yang efektif, menyenangkan, meningkatkan berpikir kritis, kreatif dalam mengembangkan materi konseptual maupun kontekstual, (c) bagi guru madarsah aliyah pada program IPS, sebagai peningkatan kompetensi profesional guru program IPS, diantaranya menyusun rencana pembelajaran dan mengembangkan pembelajaran yang mengaitkan materi konseptual dengan fenomena sosial yang ada di lingkungan serta menyusun soal berbasis HOTS sebagi alat evaluasi pembelajaran berbasis lingkungan.

\section{METODE PENELITIAN}

Penelitian ini menggunakan metode penelitian pengembangan atau Research and Development/ R\&D dari Borg \& Gall (2003) Educational research and development $(R \& D)$ is a process used to develop and validate educational products. The steps of this process are usually referred to as the $R \& D$ cycle, which consists of studying research findings pertinent to the product to be developed, developing the product based on the finding, field testing it in the setting where it wil be used eventually, and revising it to correct the deficiencies found in the field testing stage. In indicate that product meets its behaviorally defined objectives.

Langkah-langkah dalam proses ini pada umumnya dikenal sebagai siklus $R \& D$, yang terdiri dari: pengkajian terhadap hasil-hasil penelitian sebelumnya yang berkaitan dengan validitas komponen-komponen pada produk yang akan dikembangkan, menjadi sebuah produk, pengujian terhadap produk yang dirancang, dan peninjauan ulang dan mengoreksi produk tersebut berdasarkan hasil uji coba. Prosedur metode penelitian pengembangan Borg \& Gall mempunyai sepuluh langkah, namun itu bukan hal yang baku harus diikuti, langkah penelitian dapat disesuaikan dengan kebutuhan penelitian, seperti diungkap oleh Borg \& Gall dalam Emzir (2013) yang menyatakan bahwa dimungkinkan untuk membatasi penelitian dalam skala kecil, termasuk membatasi langkah penelitian. Penerapan prosedur atau langkah-langkah pegembangannya disesuaikan dengan kebutuhan peneliti, seperti pada gambar berikut: 
Gambar1: Prosedur penelitian pengembangan

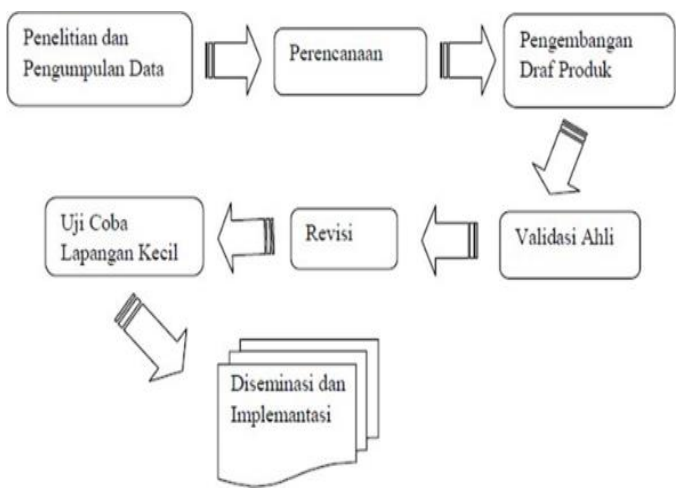

Subjek penelitian pengembangan ini adalah, guru madarsah aliayah program IPS, yaitu guru bidang studi, Geografi, Ekonomi, Sosiologi dan Sejarah. Adapun objek penelitian, adalah pembelajaran pelatihan berbasis lingkungan dengan pola blended learning yang menggunakan strategi outdoor learning pada praktik pembelajaran berbasis lingkungan, dan menyusun soal HOTS sebagai alat evaluasi pembelajaran tersebut.

Teknik pengumpulan data dan pengembangan instrumen dalam penellitian ini menggunakan: 1) Teknik pengumpulan data kuatitatif, yang meliputi: (a) angket/kuisioner validasi ahli desain program (kurikulum, silabus) pelatihan berbasis lingkungan, (b) angket validasi panduan pengembangan model pembelajaran pelatihan berbasis lingkungan, penyusunan soal HOTS, dan (c) angket respon guru program IPS MA sebagai subjek dalam penelitian ini. 2) Teknik pengumpulan data kualitatif, yaitu menggunakan teknik pedoman observasi, wawancara, angket, dokumen, dan triangulasi.

Adapun instrumen yang digunakan adalah instrumen dengan skala likert dengan kategori skor 1-4 (kurang baik, cukup, baik dan sangat baik. Instrumen digunakan untuk mengukur validitas dan reliabilitas produk yang diberikan kepada para ahli. Sedangkan untuk mengukur efektifan dalam implementasi produk dan ketercapaian tingkat pemahaman guru dalam pembelajaran berbasis lingkungan diberikan ke subjek penelitian yaitu guru madrasah aliyah program IPS, sebelum (pretest) dan sesudah (posttest) melakukan uji coba produk.

Teknik analisis data penelitian pengembangan ini menggunakan analisis data kuantitatif yang diperoleh dari data pengumpulan hasil angket dan dianalisis untuk mendapatkan gambaran tentang hasil uji coba produk dengan rumus sebagai berikut:

$$
\mathrm{P}=\frac{\Sigma \mathrm{x}}{\Sigma \mathrm{x}_{\mathrm{i}}} \times 100 \%
$$

dengan kriterian kavalidan sebagai berikut: Tabel 1: Kriteria kevalidan

\begin{tabular}{ccc} 
Nilai & Tingkat Kepraktisan & Keterangan \\
\hline $85-100$ & Sangat Praktis & Tidak revisi \\
\hline $70-84$ & Praktis & Tidak revisi \\
\hline $55-69$ & Cukup Praktis & Tidak revisi \\
\hline $50-54$ & Kurang Parktis & Revisi \\
\hline $0-49$ & Tidak Praktis & Revisi \\
\hline
\end{tabular}

Untuk uji efektifitas produk pengembangan model menggunakan uji-t/wilocxon. Sedangkan untuk analisis data kualitatif menggunakan model Miles and Huberman dalam Sugiyono (2009). Langkah-langkah model Miles Huberman seperti pada gambar berikut: Gambar2: Teknik analisis data kualitatif

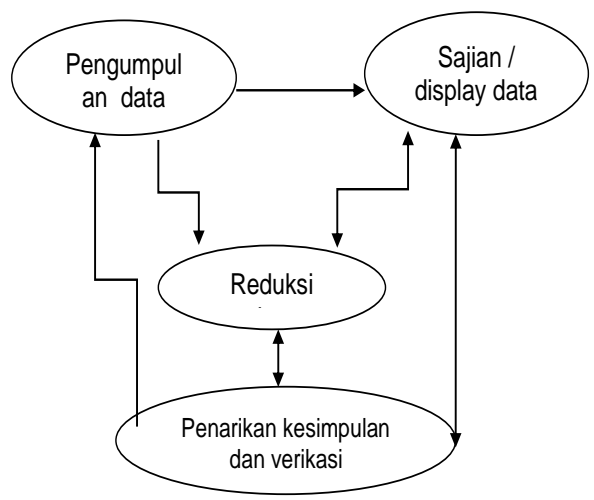

Alat yang digunakan dalam penelitian pengembangan ini berupa, handphone sebagai alat komunikasi dengan subjek penelitian, alat perekam untuk wawancara, serta kamera untuk memotret/video pada subjek maupun objek penelitian. Sedangkan bahan yang digunakan adalah, materi uji coba yang berupa rancangan program pembelajaran pelatihan berbasis lingkungan beserta panduannya. Kehadiran peneliti adalah, sebagai partisipan langsung, bergabung dengan subjek penelitian dalam aktifitas: (a) memberi penjelasan cara 
penyusunan dan praktik berkaitan dengan materi program pembelajaran berbasis lingkungan yang mencakup mata pelatihan analisis SKL, KI, KD dan Lingkungan, Rancangan Pembelajaran, Praktik Pembelajaran Berbasis Lingkungan dan Penyusunan Soal HOTS. (b) mengobservasi dengan merekam (video) aktifitas subjek penelitian dalam mengerjakan tugas dan praktik pembelajaran, (c) melakukan wawancara, (d) melakukan refleksi, dan (e) melakukan pendampingan pada waktu subjek penelitian mempraktikan pembelajaran di kelas maupun di lingkungan bersama peserta didiknya.

Informan yang membantu kelengkapan data dalam penelitian pengembangan ini, terutama pada waktu subjek penelitian melaksanakan praktik di kelas adalah, para peserta didik, kepala madrasah dan wakil kepala madrasah bidang kurikulum.

Penelitian pengembangan ini dilaksanakan di Madrasah Aliyah Negeri (MAN) 1 yang beralamat di Jl Markisa Raya II No.3 Rt.004/Rw.007 Teluk Pucung. Kec Bekasi Utara, Kota Bekasi, Provinsi Jawa Barat dan MAN $2 \mathrm{Jl}$ Bojong Asih 5 Rt.008/Rw.017. Bojong Rawalumbu. Kec Rawalumbu. Kota Bekasi. Provinsi Jawa Barat. Waktu penelitian kurang lebih dua bulan (6 Juli6 September 2020) dengan tahapan sebagai berikut: (a) pengumpulan data, (b) perencanaan pengembangan produk, (c) validasi ahli, (d) revisi, (e) uji coba lapangan, f) desiminasi hasil penelitian. Pengambilan data penelitian dengan langkah sebagai berikut: (1) pretest, (2) penjelasan rancangan kurikulum pelatihan berbasis lingkungan khususnya pada materi inti dan panduan pembelajaran, (3) uji coba rancangan kurikulum dengan panduan pembelajaran, (4) observasi uji coba dan pendampingan (5) wawancara (6) dokumen atau hasil karya uji coba (7) posttes.

\section{TEMUAN DAN PEMBAHASAN}

\section{Temuan}

Penelitian pengembangan ini menghasilkan produk yang berupa rancangan program pengembangan model pembelajaran dalam pelatihan berbasis lingkungan bagi guru madrasahaliayah program IPS dan panduan pembelajaran pelatihan berbasis lingkungan. Hasil penelitian dipe roleh dari uji coba produk yang dianalisis menggunakan data kuatitatif melalui pretest dan posttest dengan tingkat signifikansi $(\alpha)$ sebesar $5 \%$ dan $p$-value, yag kemudian dipresentase dengan perolehan hasil rancangan program mo pengembangan model pembelajaran dalam pelatihan berbasis lingkungan dengan fokus pada materi inti, yaitu Analisis SKL, KI, KD, Lingkungan, RPP, Praktik Pembelajaran, dan Penyusunan soal HOTS. Untuk hasil pretest diperoleh rata-rata $69,5 \%$, dan hasil postes rata-rata $88,5 \%$. Artinya dapat diambil kesimpulan bahwa terdapat perbedaan antara sebelum dan sesudah dilakukan uji coba produk berdasarkan seluruh aspek materi. Pada tiap aspek materi inti yang ada dalam rancangan program maupun panduan pembelajaran berbasis lingkungan secara jelas dapat dilihat pada grafik sebagai berikut:

Gambar2: Grafik perbandingan hasil uji$\mathrm{t} /$ wilocxon untuk desain kurikulum pada materi pelatihan inti:

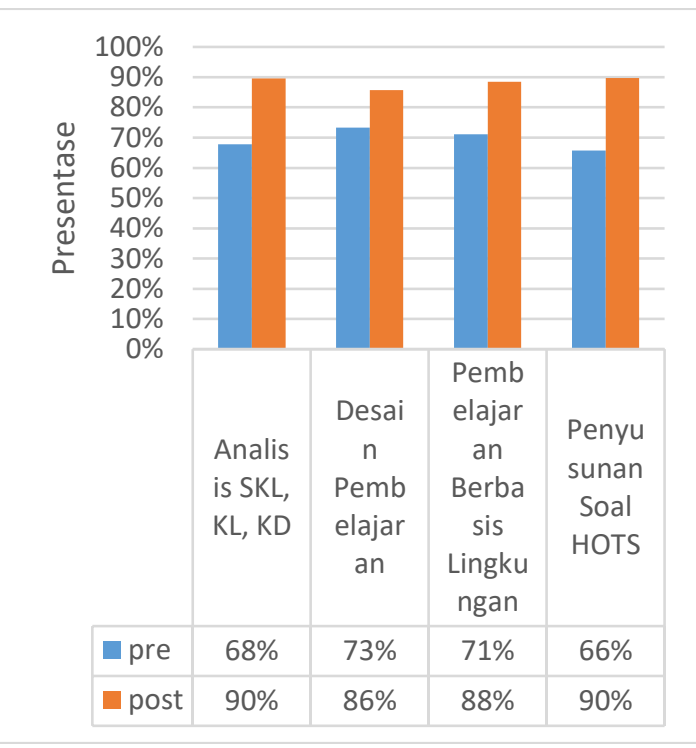

Demikian juga untuk produk panduan pembelajaran berbasis lingkungan diperoleh hasil pretest dengan skor rata-rata $70,5 \%$ dan posttest diperoleh rata-rata $88 \%$ yang artinya terdapat perbedaan antara sebelum dan sesudah dilakukan uji coba model/program lebih baik dibandingkan sebelum dilakukan uji coba model/progam. Untuk lebih jelasnya dapat dilihat pada grafik sebagai berikut:

Gambar 3: Grafik perbandingan hasil uji-t panduan pembelajaran pelatihan berbasis lingkungan program IPS MA 


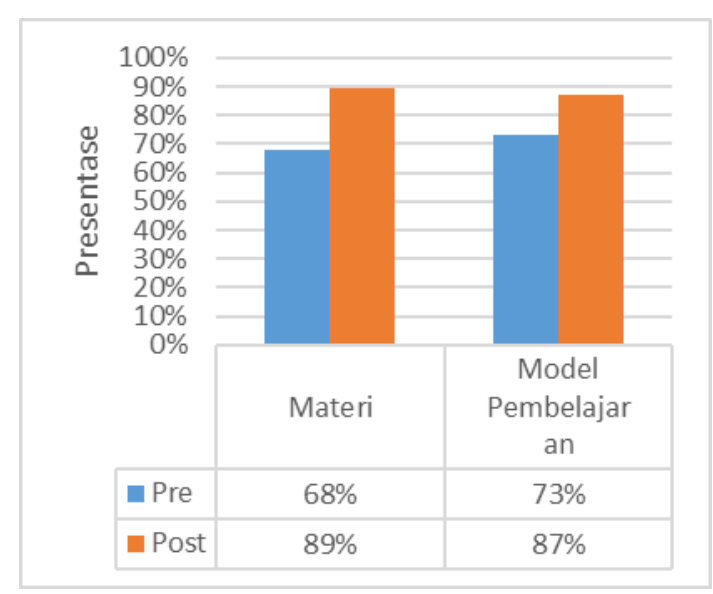

Berdasarkan hasil data kuantitatif tersebut pada produk/model, kemudian diperkuat dengan data kualitatif dengan langkah-langkah sebagai berikut: (1) pengumpulan data yang diperoleh melalui observasi, wawancara, analisis vidio, dokumen maupun angket, (2) reduksi untuk menemukan temuan hal-hal pokok pada produk/model yang diujicoba, (3) penyajian data (display), menyajikan hasil uji coba, seperti yang tertera pada tabel berikut:

Tabel 2: Display data rancangan program/kurikulum dan panduan pembelajaran pelatihan berbasis lingkungan.

\begin{tabular}{|c|c|c|c|c|c|}
\hline \multirow[t]{2}{*}{ Model } & \multirow[t]{2}{*}{ Aspek } & Angket & \multirow{2}{*}{$\begin{array}{l}\text { Observa } \\
\text { si }\end{array}$} & \multirow{2}{*}{$\begin{array}{l}\text { Hasil } \\
\text { Karya }\end{array}$} & \multirow{2}{*}{$\begin{array}{l}\text { Rata- } \\
\text { rata }\end{array}$} \\
\hline & & Pretest Postest & & & \\
\hline \multirow{4}{*}{$\begin{array}{l}\text { Kurikul } \\
\text { um } \\
\text { Pelatith } \\
\text { an }\end{array}$} & $\begin{array}{l}\text { Analisis SKL, KI, KD } \\
\text { dan Lungkungan }\end{array}$ & $68 \%$ & $90,5 \%$ & $91,5 \%$ & $90,67 \%$ \\
\hline & $\begin{array}{l}\text { Penyusunan RPP } \\
\text {. }\end{array}$ & $86 \%$ & $93 \%$ & $89,25 \%$ & $89,41 \%$ \\
\hline & $\begin{array}{l}\text { Praktik Pembelajaran } \\
\text { Berbasis lingkungan }\end{array}$ & $88 \%$ & $91 \%$ & $91,13 \%$ & $90,04 \%$ \\
\hline & $\begin{array}{l}\text { Penyusunan Kisikikisi } \\
\text { dan Soal HOTS }\end{array}$ & $90 \%$ & $90 \%$ & $88,61 \%$ & $89,53 \%$ \\
\hline $\begin{array}{l}\text { Pandu } \\
\text { an }\end{array}$ & Materi Panduan & $89 \%$ & $88 \%$ & . & $88,5 \%$ \\
\hline $\begin{array}{l}\text { Pembe } \\
\text { lajaran }\end{array}$ & Pola Pembelajaran & $73 \%$ & $89 \%$ & . & $88 \%$ \\
\hline
\end{tabular}

Data hasil uji coba tersebut mencakup dua produk dalam pengembangan model, yaitu rancangan program pelatihan berbasis lingkungan bagi guru madarsah aliyah progam IPS, dan panduan pembelajaran. Rancangan program difokuskan pada mata pelatihan inti, yaitu analisis $\mathrm{SKL}, \mathrm{KI}, \mathrm{KD}$ dan Lingkungan, rancangan pembelajaran, praktik pembelajaran berbasis lingkungan dan penyusunan soal HOTS. Sedangkan panduan pembelajaran mencakup aspek materi panduan dan pola pembelajaran. (4) Verifikasi data, untuk rancangan program pelatihan khususnya pada materi inti, yang dimulai dari penyusunan analisis diperoleh hasil akhir dengan rata-rata $89,91 \%$, hasil tersebut dikategorikan sangat layak untuk diterapkan. Sedangkan pada panduan pembelajaran hasil verifikasi data diperoleh rata-rata $88,25 \%$, artinya panduan pembelajaran pelatihan berbasis lingkungan sangat layak untuk diterapkan pada pembelajaran pelatihan berbasis lingkungan bagi guru madrasah aliyah program IPS.

\section{Pembahasan}

Hasil penelitian pengembangan ini, setiap aspek selanjutnya dibahas sebagai berikut:

a. Analisis SKL, KI, KD dan Lingkungan

Hal-hal pokok dalam pembahasan dari hasil penelitian pengembangan khususnya mata pelatihan penyusunan analisis $\mathrm{SKL}, \mathrm{KI}, \mathrm{KD}$, dan Lingkungan ini mempunyai kelayakan yang sangat signifikan yaitu diperoleh hasil pretest, posttest, observasi, dan hasil karya, dengan skor akhir rata-rata $90,67 \%$ yang kemudian dilengkapi hasil wawancara serta dokumen hasil karya.

Hal tersebut menunjukkan bahwa mata pelatihan tersebut mempunyai keunggulan sebagai berikut: (1) mampu menafsirkan dan memetakan arah dari isi $\mathrm{SKL}, \mathrm{KI}, \mathrm{KD}$ dan lingkungan, (2) pengembangan komponen $K D$, yaitu kompetensi yang dijabarkan ke indikator dan materi pembelajaran dijabarkan menjadi materi pokok, sub materi, dan sub-sub materi sesuai dengan lingkungan sebagai objek dan sumber belajar, (3) analisis menggambarkan pola kerunutan yang akan diterapkan dalam pembelajaran yang sesuai dengan kompetensi yang akan dicapai, (4) analisis dapat dijadikan silabus yang dibuat oleh guru pada beberapa pertemuan, sehingga guru mempunyai persiapan yang matang dalam melaksanakan pembelajaran, (5) analisis menunjukan keterkaitan antara kompetensi yang diharapkan oleh standar dan cara mencapai kompetensi tersebut, (6) analisis memberikan arah untuk tugas-tugas mata pelatihan berikutnya, dan (7) meningkatkan keterampilan berpikir kritis, kreatif, kolaborasi, dan komunikasi. 
Hal tersebut sesuai dengan tuntutan kompetensi pembelajaran abad 21 , yang syarat dengan pembelajaran HOTS dan diwujudkan dengan kreativitas, kritis, kolaborasi dan komunikasi serta peningkatan kemampuan menyusun soal HOTS, yang merupakan rangkaian tak terpisahkan dari pembelajaran yang kontekstual. Hasil tersebut juga mendukung hasil penelitian yang dikukan oleh Amirudin dan M. Yahya, (2019) dengan judul Analisis Validitas Dokumen SKL, KI dan KD Keselamatan, Kesehatan dan Kerja (K3) Berbasis Higher Order Thinking Skills. Hasil penelitian tersebut disimpulkan bahwa pengembangan analisis $\mathrm{SKL}, \mathrm{KI}, \mathrm{KD}$ berbasis HOTS memiliki ratarata skor 3,78 , menunjukkan sangat valid untuk diterapkan dalam pembelajaran.

Kemampuan guru dalam menyusun analisis $\mathrm{SKL}, \mathrm{KI}, \mathrm{KD}$ dan lingkungan, yang menjabarkan kompetensi pada KD sesuai dengan teori belajar kognitif dari Piaget (1988), bahwa struktur psikilogis dalam diri individu menurut Piaget disebut Skema, yang berarti kerangka mental individu yang digunakan untuk menafsirkan segala sesuatu yang dilihat atau didengarnya. Sedangkan berkaitan dengan analisis materi yang ada dalam KD dan dikolaborasi dengan analisis lingkungan yang ditentukan, merupakan pengembangan kompetensi guru dalam meningkatkan kemampuan berpikir kritis, kreativitas, kolaborasi, serta komunikasi ke arah pembelajaran yang bermakna. Dalam menganalisis KD dituntut kemampuan untuk mengembangkan kompetensi dari level satu/rendah sampai level tiga/tinggi dan mengembangkan materi dari lingkup materi pokok sampai dengan sub-sub materi yang dikolaborasi dengan materi kontekstual atau berdasarkan fenomena yang ada di lingkungan. Hal itu secara tidak langsung merupakan pendidikan lingkungan hidup, sesuai dengan hasil penelitian yang dilakukan oleh Prasetyo Adi Nugroho (2016), dengan judul Pengembangan Pembelajaran IPS Terpadu Berbasis Lingkungan, hasil penelitian menunjukkan kenaikan $74,4 \%$. Hasil tersebut sesuai kolaborasi konsep pendidikan lingkungan hidup dan pendidikan program IPS yang memiliki visi yang sejalan. Masyarakat, lingkungan dan fenomena sosial menjadi kajian utama dalam mata pelatihan program IPS, yang merujuk pada NCSS, Supardan (2015) menyampaikan bahwa visi ilmu adalah, help young people make informed and reasoned decisions for public good as citizens of a culturally diverse, democratic society in an interdependent world. Pernyataan NCSS dapat diposisikan sebagai komitmen untuk mengatasi masalah lingkungan alam maupun sosial. Hal ini merupakan persamaan visi dalam program IPS dan pendidikan lingkungan hidup dan didukung oleh hasil penelitian Stevenson (2011). Stevenson melaporkan hasil pengamatannya dengan judul Sense of Place in Australian Environmental Education Research: Distinctive, Missing or Displaced yang dipublikasikan pada Australian Journal of Environmental Education (AJEE). Hasil kajiannya, bahwa lingkungan merupakan faktor penting dalam penelitian pendidikan lingkungan. Sedangkan berkaitan dengan analisis lingkungan atau fenomena sosial yang akan menjadi objek pembelajaran adalah lingkungan. Dalam penelitian pengembangan ini lingkungan atau fenomena sosial yang dikondisikan sesuai dengan karakteristik materi dalam KD dan kompetensi yang akan dicapai.

\section{b. Penyusunan RPP}

Proses penyusunan didasarkan pada hasil analisis SKL, Kl, KD dan Lingkungan yang dijabarkan pada setiap pertemuan. Hasil penelitian pengembangan ini khususnya pada mata pelatihan Penyusunan Rencana Pelaksanaan Pembelajaran (RPP) memperoleh skor akhir rata-rata $89,41 \%$. Hasil tersebut menunjukkan kemampuan kompetensi profesional guru madrasah aliyah program IPS meningkat, sehingga mata pelatihan ini mempunyai kelayakan untuk dijadikan mata pelatihan inti dalam kurikulum pelatihan berbasis lingkungan bagi guru sebagai produk dalam penelitian ini.

Pembuktian kemampuan guru madrasah aliyah program IPS dalam menyusun RPP dibuktikan dari hasil penugasan yang berupa RPP yang memuaskan, karena telah sesuai dengan rambu-rambu penyusunan RPP sesuai Peraturan Menteri Pendidikan dan Kebudayaan Nomor 22 Tahun 2016 tentang Perencanaan Pembelajaran dan Surat Keputusan Direktur Jendral Pendidikan Agama Islam Nomor 5164 Tahun 2018 tentang 
Penyusunan RPP. Seperti yang dinyatakan oleh Briggs (1980) mengulas pendapat Gagne bahwa belajar sangat berkaitan erat dengan desain pembelajaran yang mampu mengkonstrak proses kognitif maupun keterampilan, dan tujuan pembelajaran yang akan dicapai. Hal itu seiring dengan hasil penelitian yang dilakukan oleh Juniriang Zendrato (2016) dengan judul Tingkat Penerapan Rencana Pelaksanaan Pembelajaran Dalam Pelaksanaan Pembelajaran di Kelas, dan hasilnya pada indikator tujuan belajar dan kegiatan belajar mengajar, adalah $87 \%$. Hasil penelitian pada mata pelatihan penyusunan RPP ini juga didukung teori dari Ausubel (2000), yaitu reception learning, menyarankan agar guru menyusun situasi belajar, memilih materi-materi yang tepat untuk peserta didik, dan kemudian menyampaikannya dalam bentuk pengajaran yang terorganisasi dengan baik, mulai dari yang umum ke hal-hal yang lebih terperinci.

Berdasarkan hasil penelitian dan dukungan teori tersebut $\mathrm{di}$ atas, mata pelatihan penyusunan RPP mempunyai keunggulan sebagai berikut: (a) menjadi referensi bagi guru dalam memberikan pembelajaran, (b) pembelajaran menjadi lebih sistematis dan terencana untuk mencapai tujuan pembelajaran dalam waktu tertentu, (c) alur pembelajaran menjadi lebih terarah, sebagai tempat membangun sikap, kognitif dan keterampilan, (d) meningkatkan kompetensi professional guru, (e) meningkatkan literasi bagi guru, (f) menyegarkan pengetahuan bagi guru, untuk mengingat hal-hal penting dalam proses belajar dan pengembangan materi pelajaran, (g) indikator dalam RPP menjadi acuan penyusunan soal HOTS, dan (h) evaluasi, maupun perbaikan serta pemilihan metode pembelajaran yang lebih tepat .

\section{c. Praktik Pembelajaran Berbasis Lingkungan}

Praktik pembelajaran berbasis lingkungan yang dilaksanakan secara outdoor learning yang dikondisikan sesuai RPP yang telah disusun dan analisis lingkungan yang sesuai KD serta mengacu pada panduan pembelajaran berbasis lingkungan. Hasil penelitian diperoleh skor akhir rata-rata $90,04 \%$, yang diperkuat dengan hasil wawancara, video praktik pembelajaran menunjukkan bahwa mata pelatihan praktik pembelajaran berbasis lingkungan mempunyai kelayakan yang sangat signifikan, selanjutnya diharapkan mampu merubah pembelajaran program IPS di madrasah aliyah yang tekstual menjadi kontekstual. Penkondisian pembelajaran tersebut, sesuai dengan teori behavioristik dari Skinner (1990) dikenal sebagai tokoh behavioris dengan pendekatan model instruksi langsung (directed instruction) dan meyakini bahwa perilaku dikontrol melalui proses operant conditioning. Psikologi behavioristik memandang bahwa pola-pola perilaku dapat dibentuk melalui proses pembiasaan dan penguatan (reinforcement) dengan mengkondisikan stimulus (conditioning) dalam lingkungan (environment). Demikian juga teori belajar behavioristik John B. Watson (1878-1958) dalam Hearst (Hearst, 2020) juga mempunyai kesesuaian dengan hasil penelitian pada praktik pembelajaran berbasis lingkungan ini, karena dalam teori Watson mempunyai pandangan sebagai reaksi atas teori psikodinamika, dan didasarkan dari hasil pengaruh lingkungan yang membentuk dan memanipulasi tingkah laku. Dalam penelitian ini peserta memperoleh pengalaman langsung melalui pembelajaran. Artinya bahwa lingkungan sebagai sumber belajar yang kontekstual mampu mempengaruhi pemahaman dan tingkah laku peserta, yaitu mampu megkolaborasi materi ajar secara tekstual dan materi yang kontekstual.

Berkaitan dengan lingkungan sosial menjadi sumber belajar yang kontekstual, membawa pengaruh terhadap peningkatan pemahaman suatu objek materi yang dipelajari menjadi lebih berkembang. Hal itu seiring dengan hasil penelitian yang dilakukan oleh Alien Kurniangsih, dkk. (2015) dengan judul, Penggunaan Metode Pembelajaran Outdoor Study Terhadap Pemahaman Konsep Pelestarian Lingkungan Hidup di MTs-N Singaparna. Hasil penelitian diperoleh rata-rta 72,73 menunjukkan bahwa pembelajaran dengan menggunakan lingkungan sebagai sumber belajar sangat efektif dalam mengukur pemahaman konsep terhadap pemanfaatan dan pelestarian lingkungan.

Praktik pembelajaran berbasis lingkungan dengan outdoor learning merupakan manifestasi dari pengembangan model pembelajaran dalam pelatihan program IPS secara idealis, dinamis, 
sejalan dengan NCSS (2002) yang menegaskan program IPS sebagai ilmu sosial secara mandiri atau terpadu untuk mempromosikan kompetensi kemanusiaan. Karakteristik program IPS digambarkan oleh NCSS sebagai pembelajaran yang powerful, ditandai dengan pengalaman belajar yang bermakna, terpadu, berbasis nilai, menantang, dan mengaktifkan. Berkaitan dengan pengalaman langsung yang diperoleh melalui kegiatan observasi, wawancara terhadap suatu objek, hal itu menunjukkan pembelajaran yang meningkatkan berpikir tinggi, yaitu berpikiri kreatif, inovatif dan metakognitif. Hal itu sesuai dengan pendapat Wyatt \& Looper (1999) yang dikenal dengan successful learning comes from doing atau dengan istilah kerucut pengalaman belajar, belajar akan diperoleh melalui keterlibatan dalam diskusi 50\% menyajikan/presentasi, $70 \%$ dan bermain peran/simulasi/ mengerjakan hal yang nyata $90 \%$, dengan tingkat keterlibatan dimulai dari verbal, visual, keaktifan dan melakukan. Demikian juga dengan konsep active learning dari L. Dee Fink (2013) yang menunjukkan bahwa semua aktivitas belajar melibatkan berbagai pengalaman atau dialog. Pembelajaran tersebut juga mendukung hasil penelitian yang dilakukan oleh Putri Anggita Widyastari (2019), dengan judul Studi Pelaksanaan Pembelajaran IPS Berbasis Hots (Higher Order Thinking Skills) bagi guru IPS, dan hasil penelitian menunjukkan,(1) perencanaan pembelajaran berbasis HOTS terlihat pada tujuan pembelajaran; materi pembelajaran; media pembelajaran; metode pembelajaran; evaluasi pembelajaran, (2) pelaksanaan pembelajaran HOTS terlihat dari tujuan pembelajaran memuat level

disampaikan dengan permasalahan dan bersifat komprehensip yang mendorong kemampuan berpikir peserta didik; metode pembelajaran yang digunakan berupa cooperative learning dan terdapat kegiatan menganalisis, mengevaluasi, dan membuat, serta evaluasi pembelajaran menggunakan soal HOTS.

Berdasarkan hasil penelitian dan dukungan teori dan hasil penelitian tersebut, mata pelatihan inti praktik pembelajaran berbasis lingkungan tentunya mempunyai keunggulan, yaitu: (a) peserta memperoleh pengalaman belajar secara langsung dan kongkrit, (b) membangun literasi dan komunikasi (c) mengurangi ceramah, (d) metode yang diterapkan lebh variatif, (e) pembelajaran aktif, (f) membangun kreativitas, critical thinking, (g) menyenangkan, tidak membosankan, kelas lebih terbuka, tidak terbatas pada ruang kelas pada umumnya, (h) meningkakan wawasan secara nyata, (i) berpusat pada peserta (j) pengembangan materi esensi yang kontekstual (k) pembelajaran yang membangun makna, dan (i) membangun kepedulian terhadap lingkungan sekitar.

\section{d. Penyusunan Kisi-kisi dan Soal HOTS}

Hasil penelitian pada mata pelatihan penyusunan soal HOTS menunjukkan hasil yang signifikan, yaitu diperoleh skor akhir rata-rata $89,53 \%$ artinya terdapat peningkatan kemampuan guru dalam menyusun soal HOTS Hal ini sesuai dengan hasil penelitian yang dilakukan oleh Fuaddilah Ali Sofyan (2019) dengan judul Implementasi HOTS dalam Kurikulum 2013, hasil penelitiannya menunjukkan bahwa HOTS (Higher Order Kognitif Thingking Skill) adalah suatu strategi yang dapat diterapkan atau digunakan untuk dapat menjawab persoalan-persoalan dari dampak globalisasi dan pendidikan nasional dalam rangka beradaptasi dengan masa depan dan dunia internasional.

Berkaitan hasil penelitian dalam bentuk hasil karya, yaitu kisi-kisi dan soal HOTS, yang diperoleh skor $88,61 \%$, menunjukkan kisi-kisi dan soal yang disusun sesuai dengan ketentuan soal HOTS dan adanya keterampilan guru dalam menyusun stimulus, dan daya pembeda pada pilihan jawaban, yaitu mampu menghubungkan antara materi tekstual dan kontekstual, atau bersumber pada situasi nyata. Kemampuan tersebut sesuai dengan teori belajar sosio kultural Vygotsky (1994), inti teori Vygotsky adalah menekankan interaksi antara aspek "internal" dan "eksternal" dari pembelajaran dan penekanannya pada lingkungan sosial, budaya/fenomena sosial. Kemampuan menjabarkan materi dan mengkolaborasi lingkup materi menjadi materi yang bersifat tekstual dan kontekstual, selanjutnya disusun menjadi indikator soal dengan situmulus yang menggiring berpikir tinggi (HOTS), seiring 
dengan artikel dari Alice Thomas (2009) dengan judul How to Increase Higher Order Thinking sebagai cara berpikir pada tingkat yang lebih tinggi daripada menghafal, atau menceritakan kembali dan didasarkan pada konsep taksonomi dari Bloom (1956) yang kemudian direvisi oleh Anderson, David Krathwohl, dkk, (2001), yaitu adanya level 1 LOTS (C1-C2), level MOTS 2, (C-3) dan dan level 3 HOTS (C4-C6).

Atas dasar hasil penelitian pada mata pelatihan ini mempunyai keunggulan yaitu: (a) menggiring berpikir sistematis dalam menyusun soal HOTS, (b) kisi-kisi sebagai acuan pengembangan soal dari level satu sampai dengan level tiga, (c) mengembangkan jenis soal dalam berbagai bentuk soal, (d) kerunutan antara indikator pencapaian kompetensi dengan soal, (e) kesesuaian kegiatan pembelajaran berbasis lingkungan dan berorientasi HOTS, dengan soal HOTS, (f) menggiring keterampilan berpikir tingat tinggi, karena dalam menyusun soal HOTS menggunakan beraneka stimulus, (g) dapat menjangkau lebih banyak materi/kompetensi yang akan diukur, dan (h) soal HOTS melatih menjawab soal tidak dengan spekulasi, terutama pada soal pilihan berganda maupun soal memasangkan.

e. Panduan Pembelajaran Pelatihan Berbasis Lingkungan

Panduan pembelajaran pelatihan berbasis lingkungan mencakup materi panduan dan pola pembelajaran pelatihan. Hasil penelitian pada materi panduan menunjukkan hasil yang signifikan, yaitu skor akhir rata-rata $88,25 \%$ artinya panduan mempunyai kelayakan untuk dijadikan materi panduan pembelajaran yang digunakan sebagai acuan pelaksanaan pembelajaran pelatihan berbasis lingkungan bagi guru madrasah aliayah program IPS. Panduan dalam penelitian ini merupakan produk pendukung utama terhadap penerapan produk pengembangan model pembelajaran pelatihan berbasis lingkungan, yaitu desain program kurikulum berbasis lingkungan.

Hasil penelitian yang merujuk pada materi panduan, sesuai dengan teori belajar kognitif sosial dari Bandura alih bahasa Santrok (2008, hal. 288), yaitu teori determinisme resiprokal yang terdiri dari tiga faktor utama, yaitu (1) perilaku, (2) kognitif), (3) lingkungan. Ke tiga faktor tersebut saling berinteraksi dan saling mempengaruhi dalam pembelajaran. Sedangkan pada model pembelajaran pelatihan model inon-in yang merujuk pemanfaatan teknologi. Pola blended learning menunjukkan hasil yang sangat signifikan, yaitu rata-rata $88 \%$ artinya pola blended learning dengan strategi outdoor learning, dan mengkolaborasi materi tekstual dan kontekstual sangat efektif, sehingga menghasilkan output, outcome bagi peserta maupun lembaga, karena itu layak untuk diterapkan pada pembelajaran berbasis lingkungan. Hal itu seiring dengan pendapat Jared M.C (2015), salah satu kunci pembelajaran model blended learning, adanya kolaborasi. Konstruksi pengetahuan dan keterampilan akan terjadi jika melalui proses sosial atau interaksi sosial dengan orang lain, serta adanya pendalaman materi, dan problem solving maupun project based learning. Berkaitan dengan penelitian pengembangan ini bentuk pembelajaran yang menunjukkan problem solving adalah, belajar memecahkan permasalahan berkaitan dengan materi dalam KD melalui studi kasus pada fenomena sosial sebagai stimulus dan bahan observasi pada proses pembelajaran. Sedangkan berkaitan dengan project based learning merupakan metode pembelajaran berbasis proyek, dalam hal ini peserta pada tahan on the job training, peserta diberi projek pembelajaran yang hasilnya berupa sebuah karya, yaitu analisis SKL, KI, KD dan Lingkungan, RPP, dan Soal HOTS.

Berdasarkan hasil penelitian pengembangan ini khususnya pada model pembelajaran dengan blended learning yang rata-rata memperoleh skor $88 \%$, menunjukkan bahwa model blended learning mempunyai keunggulan, sebagai berikut: a) penggabungan model kelas, tatap muka dan tidak tatap muka (online), b) kolaborasi materi tekstual dan kontekstual, c) pencapaian komptensi pengetahuan dan keterampilan secara komprehensip, d) meningkatkan motivasi dan ketuntasan belajar, e) metode pembelajaran lebih variatif dan interaktif, f) meningkatkan literasi digital, d) meningkatkan berpikir kritis dan kreativitas. Keunggulan tersebut seiring dengan hasil penelitian yang dilakukan oleh Aditia Rachman (2019) dengan judul Penerapan Model Blended learning dalam Peningkatan Hasil Belajar 
Menggambar Objek 2 Dimensi. Kesimpulan hasil penelitian tersebut sebanyak $78 \%$ peserta didik menyatakan tertarik dan menyukai model pembelajaran blended learning dan secara kontinu dapat mendorong peserta didik agar mampu meningkatkan hasil belajar dan mencapai ketuntasan dalam belajar, yang kemudian model tersebut dapat diterapkan.

\section{PENUTUP}

\section{Simpulan}

Produk

pengembangan model

pembelajaran berbasis lingkungan yang berupa desain program (kurikulum) merupakan produk dalam penelitian pengembangan ini yang disertai pruduk pendukung yaitu, panduan pembelajaran pelatihan berbasis lingkungan yang telah dilakukan uji coba melalui penelitian pengembangan ini. produk divalidasi oleh para ahli, diperoleh skor akhir rata-rata $94 \%$ untuk produk pengembangan model pembelajaran dan panduan pembelajaran diperoleh skor akhir ratarata $98 \%$. Artinya produk tersebut layak dan efektif untuk dilakukan uji coba.

Secara keselurhan diperoleh skor akhir rata-rata pada pengembangan model pembelajaran berbasis lingkungan ini diperoleh skor akhir rata-rata $89,91 \%$, disertai produk panduan pembelajaran pelatihan dengan skor akhir rata-rata $88,25 \%$. Berdasarkan tahapan penelitian pengembangan ini, yang ditekankan pada hasil uji validasi maupun uji coba produk pada guru madrasah aliyah program IPS diperoleh hasil yang sangat signifikan, sangat layak dan efektif untuk diterapkan untuk menjadi produk pengembangan model pembelajaran dalam pelatihan berbasis lingkungan dan sebagai produk pengembangan program pada Pusdiklat Tenaga Teknis Pendidikan dan Keagamaan.

\section{Rekomendasi}

Produk hasil penelitian ini dapat direkomendasikan, sebagai berikut:

(a) sebagai produk pengembangan program pada Pusdiklat Tenaga Teknis Pendidikan, (b) sebagai pengembangan jenis pelatihan khususnya bagi guru madarsah aliyah Program
IPS yang terdiri dari guru mata pelajaran Geografi, Ekonomi, Sosiologi dan Sejarah, (c) untuk mengatasi permasalahan pembelajaran khususnya pada program IPS, (d) untuk wawasan dan peningkatan kreativitas bagi widyaiswara khususnnya yang mengampu spesialisasi rumpun IPS dan (e) sebagai peningkatan kompetensi profesional guru program IPS khususnya dalam pembelajaran yang kontekstual maupun dalam penyusunan soal HOTS sebagai alat evaluasi pembelajaran. 


\section{DAFTAR PUSTAKA}

Amiruddin dan M Yahya, (2019) Analisis Validitas Dokumen SKL, KI dan KD Keselamatan, Kesehatan dan Kerja (K3) Berbasis Higher Order Thinking Skills Pada Kurikulum Sekolah Menengah Kejuruan, SEMNAS, Prosiding, Edisi $\quad 8$ Universitas Negeri Makasar, https://ojs.unm.ac.id/semnaslemlit/article/view/13737/8027

Anderson, L. W., Krathwohl, D. R., Airasian, P. W., Cruikshank, K. A., Ver, R. E. M., Pintrich, P. R., ... Wittrock, M. C. (2001). A Revision of Bloom's Taxonomyof Educational Objectives. New York: Longman.

Ausubel, D. P. (2000). The Acquisition and Retention of Knowledge: A Cognitive View. In The Acquisition and Retention of Knowledge: A Cognitive View. New York: Springer-Science Bussiness Media. https://doi.org/10.1007/978-94-015-9454-7

Bales, J. (1990). Skinner Gets Award, Ovation at APA Talk. The APA Monitor, 21(10), 1.

Bloom, B. S., \& Krathwohl, D. R. (1956). Taxonomy of Educational Objectives: The Classification of Educational Goals. New York: Longman.

Briggs, L. J. (1980). Thirty Years of Instructional Design: One Man's Experience. Educational Technology, 20(2), 45-50.

Charman, J. M. (2015). Blended Learning Design: Five Key Ingredients.

Fink, L. D. (2013). Creating Significant Learning Experiences : An Integrated Approach to Designing College Courses. New York: John Wiley \& Sons Inc.

Hearst, E. (2020). John Broadus Watson (1878-1958). In Encyclopedia.com. Encyclopedia.com.

Kurniangsih, A., Darsiharjo, D., \& Maryani, E. (2015). Penggunaan Metode Pembelajaran Outdoor Study Terhadap Pemahaman Konsep Pelestarian Lingkungan Hidup Peserta Didik di MTs.N Singaparna. Jurnal Pendidikan Geografi (Gea), 15(1). https://doi.org/https://doi.org/10.17509/gea.v15i1.4180

NCSS. (2002). National Standards for Social Studies Teachers. United States of America.

Nugroho, P. A. (2016). Pengembangan Model Pembelajaran IPS Terpadu Berbasis Lingkungan. Jurnal ilmu Pendidikan, 22(2). https://doi.org/http://dx.doi.org/10.17977/jip.v22i2.8732

Piaget, J. (1988). Antara Tindakan dan Pikiran (Alih Bahas; A. Cremers, ed.). Jakarta: Gramedia, 2008.

Rachman, A., Sukrawan, Y., \& Rohendi, D. (2019). Penerapan Model Blended Learning Dalam Peningkatan Hasil Belajar Menggambar Objek 2 Dimensi. Journal of Mechanical Engineering Education, 6(2).

Santrock, J. W. (2008). Psikologi Pendidikan (T. W. B.S., ed.). Jakarta: Kencana.

Sofyan, F. A. (2019). Implementasi HOTS pada Kurikulum 2015. Inventa: Jurnal Pendidikan Guru Sekolah Dasar, 3(1). https://doi.org/https://doi.org/10.36456/inventa.3.1.a1803

Stevenson, R. B. (2011). Sense of Place in Australian Environmental Education Research: Distinctive, Missing or Displaced? Australian Journal of Environmental Education, 27(1). https://doi.org/https://doi.org/10.1017/S0814062600000069

Supardan, D. (2015). Pembelajaran Ilmu Pengetahuan Sosial: Perspektif Filosofi dan Kurikulum. Jakarta: Bumi Aksara.

Thomas, A., \& Thorne, G. (2009). How to Increase Higher Order Thinking. Reading Rockets.

Vygotsky, L. S. (1994). Mind in Society: The Development of Higher Psychological Processes. Cambridge: Harvard University.

Widyastari, P. A., \& Supardi. (2019). Studi Pelaksanaan Pembelajaran IPS Berbasis Hots (Higher Order Thinking Skills) Di Smp Negeri 5 Yogyakarta. Social Studies, 8(1).

Wyatt, R. L., \& Looper, S. K. (1999). So You Have to Have a Portfolio: A Teacher's Guide to Preparation and Presentation. SAGE Publications.

Zendrato, J. (2016). Tingkat Penerapan Rencana Pelaksanaan Pembelajaran dalam Pelaksanaan Pembelajaran di Kelas Suatu Studi Kasus di SMA Dian Harapan Jakarta. SCHOLARIA: Jurnal Pendidikan dan Kebudayaan, 6(2). https://doi.org/https://doi.org/10.24246/j.scholaria.2016.v6.i2.p58-73 